\title{
M-Government Services Initiatives in Oman
}

\author{
Syed Jafar Naqvi and Hafedh Al-Shihi \\ Sultan Qaboos University, Al-Khod, Sultanate of Oman
}

\author{
cce3249@squ.edu.om; hafedh@squ.edu.om
}

\begin{abstract}
Information technology and communications have now become the main elements that move forward and help Oman in its national development process. Internet penetration in most developing countries like Oman is still low as oppose to mobiles dissemination, despite the government plans and strategies to enhance internet diffusion. Internet subscribers comprised about $2.5 \%$ of the general population of Oman. In contrast, the number of mobile holders increased substantially since the launch of these services in 1996. Prepaid mobile services and SMS were introduced in 2001 and both are currently popular with subscribers. Such fine appeal influenced many government organizations to go mobile with the ir services. This paper reviewed the ICT sector and the current $\mathrm{m}$-government initiatives in Oman setting up the mobile services and aimed to understand the key factors to adoption and diffusion of these services.
\end{abstract}

Keywords: Oman, e-government, m-government, technology adoption, success factors

\section{Introduction}

Mobile devices are now becoming part of our daily and business life. At the end of year 2001, approximately $14 \%$ of the world population - 850 Million people - were mobile phone users. This growth has been spectacular especially in Europe after the telecom industry de-regulation and adoption of Global System for Mobile (GSM) communications (Sadeh, 2002). Now, mobile phones are no longer used only for voice communication but are a convenient way of connecting to the Internet and are used for transferring data, exchanging e-mails, and doing small scale business transactions (Sadeh, 2002). Mobile phone penetration is well above the home PCs usage in Europe and it seems that the trend will continue (Varshney, 2000). Mobile or wireless devices are widely used not only by developed countries but also commonly used by many other developing nations of the world and Oman is not an exception.

Mobiles technologies with the introduction of internet enabled mobile phones, PDA's, WiFi and wireless networks have offered their users to enjoy all the benefits of telephones, information accessing, text messaging such as SMS (Clark, 2001; Donegan, 2000; May, 2001). A recent estimate indicated that over half of the Omani populations have mobile devices, while the mobile

Material published as part of this publication, either on-line or in print, is copy righted by the Informing Science Institute. Permission to make digital or paper copy of part or all of these works for personal or classroom use is granted without fee provided that the copies are not made or distributed for profit or commercial advantage AND that copies 1) bear this notice in full and 2) give the full citation on the first page. It is permissible to abstract these works so long as credit is given. To copy in all other cases or to republish or to post on a server or to redistribute to lists requires specific permission and payment of a fee. Contact Publisher@InformingScience.org to request redistribution permission. infrastructure in Oman is currently covering $95 \%$ of the country (Ministry of National Economy, 2007). The volume of penetration of mobile devices in the country is paving the path for more offering of m-government services accessible from anywhere and at any time. This lead to mobile government activities reaching a larger base in a more convenient manner. 
Thus, several organizations in Oman have started to utilize this to open mobile channels with their clients. Muscat Municipality developed an m-parking system which enables motorists to pay parking fees via SMS. In addition, higher secondary school students can now retrieve their end of semester grades (via SMS) by messaging their student seat numbers to a phone number designated by ministry of education. Many other organizations are now sending bulk SMS messages to citizens to inform them about different activities. Despite its early stage, $\mathrm{m}$-government seems to have a substantial influence on the current m-government services initiatives in Oman, which are further needed to be explored.

Purpose of the study: In this paper, an attempt is made to review the current m-government services initiatives in Oman and to understand the key factors to its adoption and diffusion.

\section{Background to the Study}

The Sultanate of Oman is a developing country, which is located on the south east of the Arabian Peninsula. Oman occupies an area of 309,500 square kilometers (Ministry of Information Oman, 2008b). It shares borders with United Arab Emirates to the north-west, the Kingdom of Saudi Arabia to the west, the Republic of Yemen to the south and the Arabian Sea lies eastwards. Oman is divided into five regions i.e. Ad-Dakhliyah, Adh-Dhahirah, Al-Batinah, Al-Wusta and Ash-Sharqiyah and four governorates i.e. Al Buraymi, Dhofar, Musandam and Muscat. The total adult literacy in Oman is $81 \%$ which is very high in the region and per capita income reaching to US\$ 9070. Oman's real renaissance began with the accession of His Majesty; Sultan Qaboos bin Said Al Said to the throne on 23 July 1970 (Ministry of Information - Oman, 2008a). Oman's government system is monarchy (Ministry of Information - Oman, 2008a).

According to the latest estimates (Ministry of National Economy - Oman, 2007), in 2006 Oman had a population of 2.677 million people. However, nearly 693,000 residents, 25.9 per cent of the population, were expatriates. Oman's currency is the Rial (OMR) which is about USA \$2.60 per unit. The country's main revenue comes from oil and natural gas. According to the Ministry of National Economy - Oman (April 2008), Oman's 2006 GDP reached OMR 13,737 million (provisional), compared to OMR 104 million in 1970. The country's economic status was substantially enhanced by ris ing oil prices. The United Nations Economic and Social Commission for Western Asia (ESCWA, 2007) estimated Oman's GDP in 2005 to be US $\$ 30,834$ millions.

\section{ICT Sector}

The Information and Communications Technology (ICT) sector in Oman is at an early stage of development, but it is quickly gaining momentum. The government is currently undertaking a comprehensive planning and development program for the sector. The National Committee for Information Technology was established in 1998 to address issues in Oman's information and communications sector. The Committee is chaired by the Minister of National Economy (ESCWA, 2007).

In April 2000, the Committee formed the 'Information Technology Task Force' (ITTF) (AIEsmaeli, 2002) to deve lop an IT vision for Oman. The Task Force's deliberations produced the following statement: "The leveraging of Information Technology \& communications in providing collaborative services to public \& private sectors and citizens through electronic means as being the driving force to move forward the Sultanate to the Knowledge Based Economy and achieve sustainable development' (National Committee for Information Technology - Oman, 2003). Later on an Information Technology Authority (ITA) was established by the Royal Decree No. 52/2006 to oversee Oman's ICT sector and Digital Oman strategy of which e-government is a subset (ESCWA, 2007). Oman had OmanTel as the only service provider for both mobile and fixed tele- 
communication services until 2004, when Nawras became a second provider, though it offered mobile services only.

The adoption rate among the key ICT services varies in Oman. According to Ministry of National Economy Oman (2008), the number of internet subscribers and mobile subscribers are increasing, while the number of fixed phone subscribers is reducing. There is a $6 \%$ reduction of fixed phone subscribers in 2007 in comparison to year 2006 as shown in Figure 1. During the same period, there is a sharp rise $40.4 \%$ of mobile phone prepaid subscribers and $19.3 \%$ rise in postpaid services as shown in Figure 2.

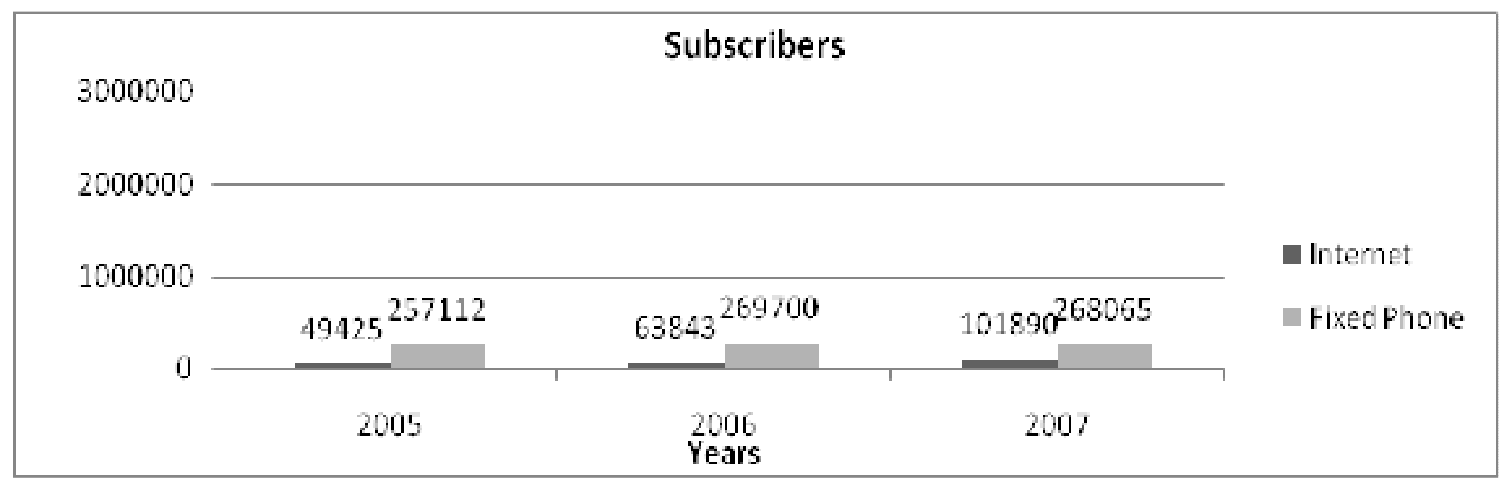

Figure 1: Subscribers of Inte rnet and Fixed Phones

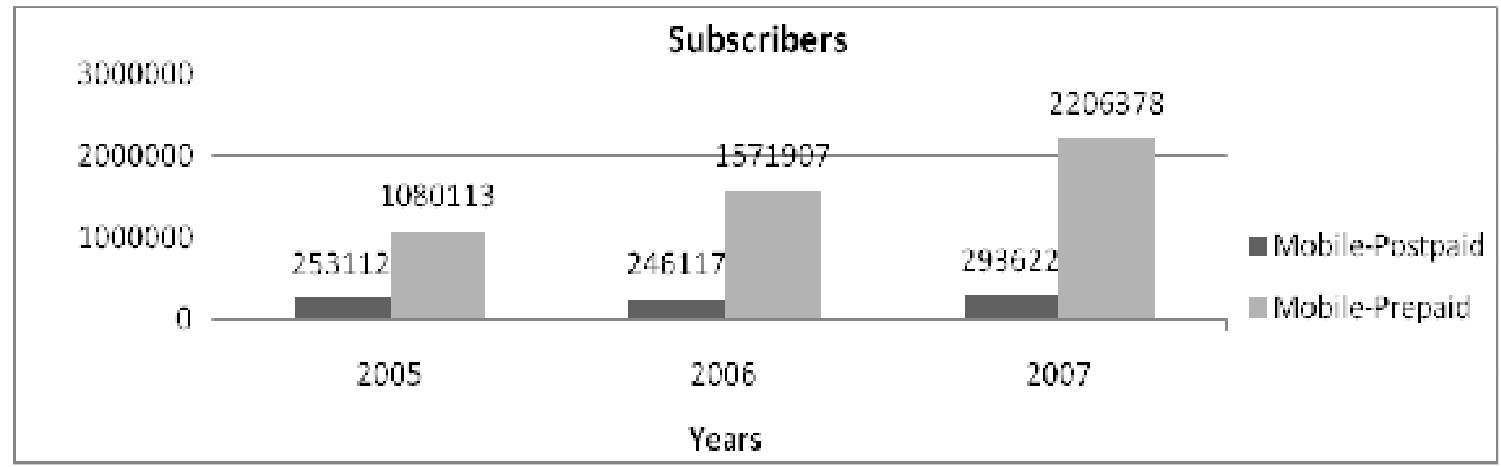

Figure 2: Subscribe rs of Mobile Post and Prepaid

In addition, multimedia message services (MMS), general packet radio service (GPRS) and wireless application protocol (WAP) were introduced at the end of 2004 (ESCWA, 2005) while the third generation (3G) mobile services have been launched by Nawras at the end of 2007 (Nawras, 2008).

OmanTel is developing and upgrading its services to provide better and efficient services to its telephone and internet subscribers. As Oman is participation in a Falcon submarine cable venture, a high-capacity loop cable system that extends from the Middle East and Egypt through India to China, with Muscat as one of the hub cities. Flag Telecom, a leading global network services provider, funded the project together with India's Reliance Infocomm (AME Info, 2004; \& Alwatan, 2004). This extra capacity was instrumental in increasing the number of Omani internet subscribers.

\section{M-government Services}

As mentioned earlier, over half of the Omani population has mobile devices. Thus, several organizations in Oman have started to utilize this to open mobile channels with the ir clients. This section outlines the major m-government services in Oman categorized in two groups; push and 
pull services. Push services are passive in nature where clients or end-users usually receive notifications about certain activities or events. On the contrary, Pull services ask users to play more active role in either initiating the service or responding to queries via mobile devices.

\section{Push services}

Muscat Securities Market has developed a paid service that enables investors to receive regular updates on market and stock alerts via SMS (Oman Mobile, 2007b). The service also enables users to get an SMS every 30 minutes on market movers - top winners, losers and most active companies (Oman Mobile, 2007c).

The Civil Aviation and Meteorology in cooperation with Oman Mobile has introduced a weather forecast service for most towns in Oman that allows users to receive weather reports on their mobiles (Oman Mobile, 2007d).

Other public organizations have also started to send bulk messages to citizens informing them about certain activities and events. For example, the Public Authority for Social Insurance has currently begun a public campaign to publicize its services and their perceived benefits to clients. One of the means used was to send advertising SMS to all residents in Oman. Another example is in Oman Tender Board and Ministry of Manpower where they now send notification messages to clients about their transactions and/or other different issues such as new tenders and job vacancies etc.

\section{Pull services}

Muscat Municipality developed an m-parking system which enables motorists to pay parking fees via SMS (Muscat Munic ipality, 2007). Drivers can now SMS details of the ir vehic le plate number to a short code number ' 90091 ' and get a confirmation message with allocated time. Five minutes before the allocated time expires, the municipality sends a reminding message to motorists asking them either to move their vehic les or renew their parking.

The Royal Oman Police (ROP) initiated a mobile service allowing drivers to inquire and receive information about their traffic offences. Motorists are required to send a message of their ID and vehic le details to '3004' and will receive information on the number of traffic offences and amount payable. ROP plans to enable the system to notify drivers of their offences as soon as they happen, which will be useful to parents of their sons and daughters driving activities and business owners can keep monitoring of their company's drivers violations on time which can help in reducing the traffic offences.

The Ministry of Education now sends the final general certificate results to students via SMS.

Alternatively, students can inquire about their results by messaging their seats numbers to '92020' and receive their final marks (Oman Mobile, 2007a). In addition, the Higher Education Admiss ion Center now informs students of their admission status in different institutions via SMS allowing them to accept or reject the offer by messaging back their choice.

\section{Methods and Discussions}

To collect information, on the issue of m-government services initiatives in Oman and to understand the success and failure factors, interviews were conducted with key staffs in several government organizations. These organizations were chosen according to their respective experiences in m-government and only the active adopters were chosen and their key staffs were interviewed. Key staffs were chosen according to the ir job titles and responsibilities. The purpose of these interviews was to collect the data on issues related to ICT sector and m-government initiatives in Oman. The data analyses were done using the SWOT (Strengths, Weaknesses, Opportunities and 
Threats) analysis method and the results on the issues related to m-government services adoption and diffusion in Oman presented in the following Table 1.

Table 1 A SWOT analys is results on Oman's ICT sector

\begin{tabular}{|c|c|}
\hline gths & Weaknesses \\
\hline $\begin{array}{ll} & \text { Sound economy and good interna- } \\
\text { - } & \text { Stable political system and peaceful } \\
& \text { society } \\
\text { - } & \text { High literacy rate } \\
\text { - } & \text { Strong leadership support } \\
\text { - } & \text { Comprehensive mobile coverage } \\
\text { - } & \text { Government support to private sector } \\
\text { - } & \text { Strategic geographic location } \\
\text { - } & \text { Majority of population aged } \\
\text { - } & \text { 15-65 years - i.e. working age. }\end{array}$ & 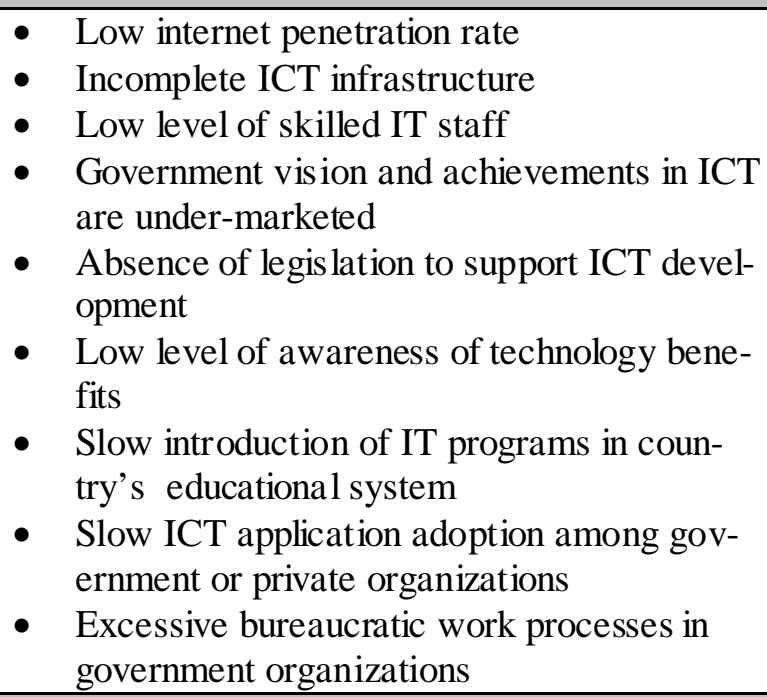 \\
\hline$\overline{\mathrm{OpI}}$ & Threats \\
\hline $\begin{array}{l}\text { - } \begin{array}{l}\text { B2C and B2B outputs are expected to } \\
\text { expand swiftly }\end{array} \\
\text { - Support for ICT liberalization strategy } \\
\text { is part of WTO agreement } \\
\text { - } \quad \text { Government support for privatization } \\
\text { of ICT sector } \\
\text { - Successful e-government and m- } \\
\text { government projects in ne ighboring } \\
\text { countries } \\
\text { - High adoption rate of mobile tele- } \\
\text { communications services in neighbor- } \\
\text { ing countries } \\
\text { - Flexible society open to change }\end{array}$ & $\begin{array}{l}\text { - Lack of priority to integrate central e- } \\
\text { government through all-government steering } \\
\text { committees work } \\
\text { - Government organizations have different } \\
\text { rates of e-government adoption } \\
\text { - Government organizations work and set } \\
\text { plans in isolation from each other } \\
\text { - Frequent structural changes within govern- } \\
\text { ment organizations affect ICT implementa- } \\
\text { tion } \\
\text { ICT sector growth is mainly dependent on } \\
\text { the public sector demands. }\end{array}$ \\
\hline
\end{tabular}

These analyses showed that Oman faces many critical issues that need to be addressed. Apparently, many of the issues (Weaknesses and Threats) are more cultural and country-specif ic than technical in nature. These factors act as inhibitors to adoption and growth in many instances. That is, they negatively influence users in their decision to use the technology and also restrict decision makers from implementing or taking initiatives to adopt m-government services. For example, the absence of e-legis lation that governs online and mobile activities and the low level of $\mathrm{m}$ government awareness and IT literacy limit the contributions and involvement of users in any mgovernment project. Subsequently, this will hold back development and growth in this domain that is primarily based upon users' needs and involvement.

The same issues might also prevent senior private-sector officials from embracing new technologies. Based on the analyses a list of factors critical to the successful implementation of $\mathrm{m}$ government services in Oman is presented as follows: 


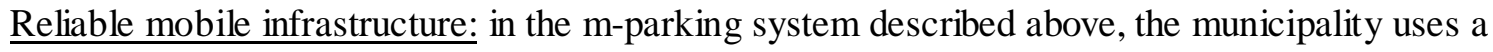
PDA connected to the GPRS network to check if vehicles are legally parked. Obvious ly if the mobile network is temporary down, the mobile parking system will be affected too. Moreover, such incident may cause faulty ticketing to legally parked vehicles, which could negatively influence users trust and satisfaction, and degrade the system image.

3G Network: several officials declared that the absence of $3 \mathrm{G}$ network in Oman and the current high costs of MMS and WAP limit adopters and developers to certain kinds of mobile applications. Generally, SMS technology will only be utilized, which is limited to text and number of characters.

Solid marketing campaigns: justifying marketing costs among government organizations might be a dilemma. Despite this, users must be made aware of the initiatives and their perceived usefulness to them. They should also be informed on how to use the mobile services. More importantly, Omani citizens are seen to be prone to stereotyping, and hence, ensuring proper implementation of programs and successful experiences to users is a step that should precede advertising. There are very low chances that users will trust or keep trying any m-solution if it has shown to be faulty from the first few attempts.

Security and Privacy: Users' information and transactions should be kept confidential and solid security measures must be observed. Ministry of Education used to publish the results of the general certificate students on newspapers, which received many privacy concerns. The current mobile system ensures privacy by allowing students and their parents only to receive the results. On the other hand, the Higher Education Admission Center m-service described above lacked usability as students questioned its security standards.

\section{Summary and Conclusion}

The research on issues related to e-government, m-government adoption in Oman was not very much undertaken. This study reviewed the ICT sector and the current $\mathrm{m}$-government initiatives in Oman and aimed to understand the key factors to adoption and its diffusion. The popularity of mobile devices, in the country, is on the rise in turn creating more opportunities for the $\mathrm{m}$ services. There are clear potentials to these services in Oman and the government must consider more mobile applications in parallel with the current e-government projects for modernization of the public administration. The current m-government initiatives are popular with users, which emphasize the possibility of $\mathrm{m}$-government to be a driving force for more e-government adoption and dissemination.

The coming age of m-government raises several interesting questions. Will m-government replace the e-government activities? Despite its significance m-government cannot be seen as replac ing e-government and in many cases it will be complementary to e-government efforts. The conventional e-government efforts provide services through wired network with interactive and relatively intelligent web applications. The value of m-government comes from the capabilities of applications supporting mobility of the citizens, businesses and internal operations of the governments for example: crimes, accidents, safety and other public issues.

\section{References}

AlEs maeli, S. (2002). 'Oman e-government strategy' in higher leadership symposium on e-govern ment. Innovation and Challenges to the $21^{\text {st }}$ Century Managers, General Management Institute, Muscat.

Alwatan. (2004). Falcon strengthen communication infrastructure in Oman. Al-Watan, 31 ${ }^{\text {st }}$ May, p. 12.

AME In fo. (2004). FALCON launch held in cable hub city of Muscat. Retrieved December 13, 2008 fro m http://www.ameinfo.com/57665.html 
Clarke, III, I. (2001). Emerg ing value propositions for M-commerce. Journal of Business Strategies, 18(2), 133-148.

Donegan, M. (2000). The m-commerce challenge. Telecommunications, 34(1), 58.

ESCWA. (2005). Regional profile of the information society in western Asia. United Nations, New York.

ESCW A. (2007). National profile for the information society in the Sultanate of Oman. Un ited Nations, New York.

May, P. (2001). Mobile commerce: Opportunities, applications, and technologies of wireless business. New York, NY: Cambridge University Press.

Ministry of National Economy - Oman (2003). 'Profile of the information society in the Sultanate of Oman' in information society profiles for western Asia 2003. ESCW A [CD ROM].

Ministry of National Economy - Oman (2007). Statistical year book, Vol. 35.

Ministry of Information - Oman (2008a). His Majesty Sultan Qaboos bin Said. Retrieved December 13, 2008, fro $\mathrm{m}$ http://www.omanet.om/english/history/sultan.asp?cat=hist

Ministry of Information - Oman (2008b). Useful information. Retrieved December 13, 2008, from http://www.o manet.o m/english/useful/basic.asp?cat=use

Ministry of National Economy - Oman. (2008, April). Monthly statistical bulletin, 19(4).

Nawras. (2008). Nawras customers get more faster with 3G+. Retrieved December 13, 2008, from http://www.nawras.om/about nawras media centre press releases $07102 . \mathrm{shtml}$

Sadeh, N. (2002). M-Commerce: Technologies, services, and business models. Hershey, PA: W iley Computer Publishing.

Varshney, U., \& Vetter, R. (2000). Emerging mobile and wireless networks (Technology information), Communications of the ACM.

\section{Biographies}

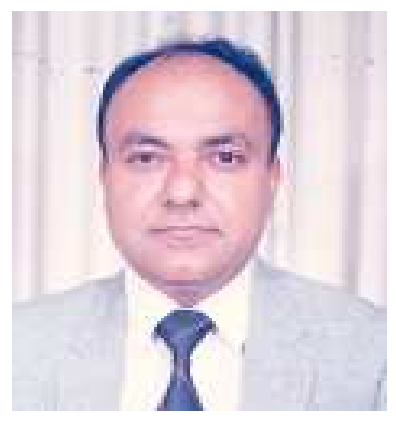

Syed J. Naqvi is an Assistant Professor in the Department of Information Systems, College of Commerce and Economics at Sultan Qaboos University. Prior to this he worked at many other prestigious universities and published widely on Computers and Information Systems education. His teaching interests include programming languages, Web applications development, e-commerce and computer networking with research interest in computer education.

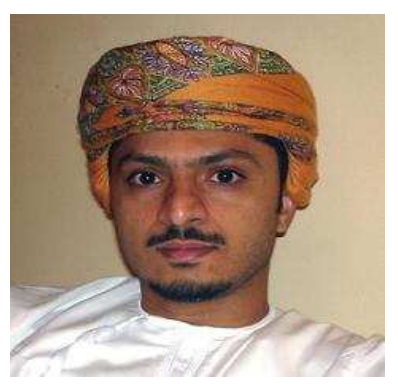

Hafedh AIShihi is an Assistant Professor at the College of Commerce and Economics in Sultan Qaboos University. He has finished his $\mathrm{PhD}$ in e-government at Victoria University in Melbourne, Australia in 2006, and his MSc in Computer and Information Systems at University of Detroit Mercy in Michigan, USA. He is a member of the Association of Information Systems (AIS) and the Special Interest Group on Electronic Government (SIGeGov). He is also a Research Associate in the Center for International Corporate Governance Research at Victoria Univers ity, Australia. He has several publications on e-government adoption and dissemination and has attended several local and international conferences. He has been selected to be in the reviewing committee of several international conferences and journals such as the Journal of Information Technology for Development and the International We-B 
(Working for E-Business) Conference in Australia. He has supervised several undergraduate, masters and $\mathrm{PhD}$ researches, several of which has been accepted in international conferences and received national and international recognition. Currently, he is teaching introductory and major Information Systems (IS) courses to undergraduate students and supervis ing the Information Systems Group at the Sultan Qaboos University (www.isg-zone.com). 